TORCH study. Am J Respir Crit Care Med 2008;178(4):332-8. http://dx.doi.org/10.1164/rccm.200712-18690C

99. Tashkin DP, Celli B, Senn S, et al. A 4-year trial of tiotropium in chronic obstructive pulmonary disease. N Engl J Med 2008;359(15):1543-54. http://dx.doi.org/ 10.1056/NEJMoa0805800

100. Tashkin DP, Rennard SI, Martin P, et al. Efficacy and safety of budesonide and formoterol in one pressurized metered-dose inhaler in patients with moderate to very severe chronic obstructive pulmonary disease: results of a 6-month randomized clinical trial. Drugs 2008;68(14):1975-2000. http://dx.doi.org/ 10.2165/00003495-200868140-00004

101. Rennard SI, Tashkin DP, McElhattan J, et al. Efficacy and tolerability of budesonide/formoterol in one hydrofluoroalkane pressurized metered-dose inhaler in patients with chronic obstructive pulmonary disease: a results from a 1-year randomized controlled clinical trial. Drugs 2009;69(5):549-65. http://dx.doi.org/10.2165/00003495-200969050-00004

102. Lizak MK, Nash E, Zakliczynski M, Sliwka J, Knapik Pm, Zembala M. Additional spirometry criteria predict postoeperative complications after coronary after bypass grafting (CABG) independently of concomitant chronic obstructive pulmonary disease: when is off-pump CABG more beneficial? Pol Arch Med Wewn 2009;119(9):550-7.

103. Haave E, Skumlien S, Hyland ME. Gender considerations in pulmonary rehabilitation. J Cardiopulm Rehabil Prev 2008;28(3):215-19.
104. Foy CG, Rejeski WJ, Berry MJ, Zacarro D, Woodard CM. Gender moderates the effects of exercise therapy on health-related quality of life among COPD patients. Chest 2001;119(1):70-6. http://dx.doi.org/10.1378/chest.119.1.70

105. Franklin KA, Gustafson T, Ranstam J, Strom K. Survival and future need of longterm oxygen therapy for chronic obstructive pulmonary disease - gender differences. Respir Med 2007;101(7):1506-11. http://dx.doi.org/10.1016/ j.rmed.2007.01.009

106. Machado MC, Krishnan JA, Buist SA, et al. Sex differences in survival of oxygendependent patients with chronic obstructive pulmonary disease. Am J Respir Crit Care Med 2006;174(5):524-9. http://dx.doi.org/10.1164/rccm.200507-10570C

107. Centers for Disease Control and Prevention. Chronic obstructive pulmonary disease - United States, 2000-2005. Morb Mortal Wkly Rep 2008;57(45):1229-32.

108. Cote CG, Pinto-Plata VM, Marin JM, Nekach H, Dordelly L, Celli BR. The modified BODE index: validation with mortality in COPD. Eur Respir J 2008;32(5):1269-74. http://dx.doi.org/10.1183/09031936.00138507

109. Lange P, Nyboe, Appleyard M, Jensen G, Schnor. Relation of ventilatory impairment and of chronic mucus hypersecretion to mortality from obstructive lung disease and from all causes. Thorax 1990;45(8):579-85. http://dx.doi.org/ 10.1136/thx.45.8.579

110. Nilsson S, Carstensen JM, Pershagen G. Mortality among male and female smokers in Sweden: a 33 year follow up. J Epidemiol Community Health 2001;55(11):82530. http://dx.doi.org/10.1136/jech.55.11.825

\title{
COMMENTARY
}

\section{Sex and gender differences in COPD: challenging the stereotypes}

\section{*Audrey DunnGalvina}

${ }^{a}$ Department of Early Years and Childhood Studies, Department of Paediatrics and Child Health, University College Cork, Ireland.

The relationship of sex and gender to health and disease is complex, and varies across an individual's lifespan. This has implications for (potentially) differing patterns of disease prevalence, different degrees of severity, and different patterns of mortality and morbidity between men and women. ${ }^{1,2}$

Sex denotes the differences attributed to biological origins alone, while gender refers to the social and cultural influences that lead to differences between women and men. ${ }^{3}$

Chronic obstructive pulmonary disease (COPD) is an increasing cause of morbidity and mortality worldwide. Although COPD has historically been considered a disease of male smokers, it now clearly impacts on both sexes. ${ }^{4}$ As Ohar, Fromer, \& Donohue point out in this helpful review, ${ }^{5}$ the paradigm of COPD is changing from a male-predominant two-category disorder, to a disorder characterised by multiple co-morbidities with a growing female prevalence.
Careful evaluation, and a raised awareness of the possibility that sex or gender (or both) may influence COPD susceptibility and progression, is of critical importance for two main reasons: firstly, because the potential future impact of the disease may have been underestimated; ${ }^{4}$ and secondly, because the condition is primarily diagnosed and managed by general practitioners (GPs). GPs are as vulnerable as their patients to sex and gender stereotypes, and this can impact on information processing and decision-making.

This review ${ }^{5}$ highlights key research areas in COPD where sex and gender stereotypes can be challenged - including disease susceptibility, symptoms, treatment, prognosis, and diagnosis. Although biological determinants of sex and age differences in airway behaviour (dimensional, immunological, and hormonal) have been known for many years, ${ }^{6}$ there are still major gaps in our knowledge about COPD phenotypes. In particular, little is known about the mechanisms and

\footnotetext{
* Corresponding author: Dr Audrey DunnGalvin, Department of Early Years and Childhood Studies, Department of Paediatrics and Child Health, College Rd, University College Cork, Cork City, Ireland. Tel: 00353-21-4902684 E-mail: A.DunnGalvin@ucc.ie
} 
implications of a possible gender difference in COPD. Although much research suggests that disease and health problems may be experienced very differently by men and women - with different implications in terms of lifestyle, health status, and outcomes ${ }^{7.8}$ - the demonstration of gender differences in COPD can be challenging, especially in crosssectional and case-control studies. For example, the proportion of females to males is typically lower in many COPD studies, and female participants have typically smoked significantly less than men. ${ }^{4}$

Although it is helpful to dichotomise male/female differences into those that are potentially sex-related versus those that are gender-related, it is difficult to disentangle the relative contribution of sex/gender because of the complexity of their interactions. For example, the authors draw attention to gender differences in self-reporting, perception of quality of life, and emotional impact (e.g. depression, anxiety) in COPD. ${ }^{5}$ Such differences in self-report and even prevalence could, at least in part, be explained by sex differences in the physiological response to stress, and gender differences in the types of stressors to which an individual is likely to be exposed. In turn, the nature of stressors may influence sex differences in physiological reactivity to stress, ${ }^{9}$ with genderspecific impact on perception of symptoms, information processing, and role expectations. ${ }^{10}$

The value of integrated approaches has been clearly demonstrated in recent years. It is now generally recognised that failure to incorporate sex and gender in research designs can result in failures of both effectiveness and efficiency. ${ }^{11}$ The new paradigm of evidence-based medicine has underscored this awareness and driven the debate on the limited generalisability of findings that do not take sex and gender into account in clinical research. This clinical review paper is a welcome addition to the debate.

\section{Conflicts of interest}

The author declares that she has no conflicts of interest in relation to this article.

\section{References}

1. Doyle L. Gender equity in health: debates and dilemmas. Soc Sci Med 2001; 51:931-9.

2. Wizeman TM, Pardue ML (editors). Exploring the biological contributions to human health: does sex matter? Washington, DC: National Academy Press, 2001

3. Klinge I, Bosch M. Gender in research: Gender impact assessment of the FP5 Specific Programmes. 'Quality of life and management of living resources'. A study for the European Commission, EUR20017.

4. DeMeo D. The yin and yang of COPD: Sex/gender differences in the National Emphysema Treatment Trial. Am J Resp Crit Care Med 2007;176:222-3.

5. Ohar J, Fromer L, Donohue JF. Reconsidering sex-based stereotypes of COPD. Prim Care Respir J 2011;20(4):370-78. http://dx.doi.org/10.4104/pcrj.2011.00070

6. Becklake MR, Kauffman F. Gender differences in airway behaviour over the lifespan. Thorax 1999;54:1119-38.

7. Wieringa NF, Hardon AP, Stronks K, M'charek AA, editors. Diversity among patients in medical practice: challenges and implications for clinical research. Amsterdam: Universiteit van Amsterdam, 2005

8. White A, Cash K. The state of men's health in 17 European countries. Brussels: The European Men's Health Forum., 2003. European Institute of Women's Health. Women's Health in Europe. http://www.eurohealth.ie/ .

9. Kang DH, Kim CJ, Suh R. Sex Differences in Immune Responses and Immune Reactivity to Stress in Adolescents. Biological Research For Nursing 2004;5(4):24354.

10. DunnGalvin A, Hourihane JOB, Frewer L., Knibb RC, Oude Elberink JN. Klinge I. Incorporating a gender dimension in food allergy research: A review. Allergy 2006; 61(11):1336-43.

11. Global Forum for Health Research. Sex, gender and the 10/90 gap in health research. 2003 (http://www.globalforumhealth.org/Site/000_Home.php).

Commissioned article; not externally peer-reviewed; received 18th November 2011; accepted 18th November 2011; online 22nd November 2011

(C) 2011 Primary Care Respiratory Society UK. All rights reserved. A DunnGalvin. Prim Care Respir J 2011;20(4):378-379.

http://dx.doi.org/10.4104/pcrj.2011.00107

Available online at http://www.thepcrj.org 